\title{
Elemental composition of Malawian rice
}

Edward J.M. Joy ${ }^{1,2,3}$, E. Louise Ander ${ }^{2}$, Martin R. Broadley ${ }^{3}$, Scott D. Young ${ }^{3}$, Allan D.C. Chilimba ${ }^{4}$, Elliott M. Hamilton ${ }^{2}, \underline{\text { Michael J. Watts }}^{2}$

${ }^{1}$ Department of Population Health, London School of Hygiene \& Tropical Medicine, Keppel Street, London WC1E 7HT, UK

${ }^{2}$ Inorganic Geochemistry, Centre for Environmental Geochemistry, British Geological Survey, Keyworth, Nottingham, NG12 5GG, UK

${ }^{3}$ School of Biosciences, University of Nottingham, Sutton Bonington Campus, Loughborough, LE12 5RD, UK

${ }^{4}$ Department of Agricultural Research Services, Ministry of Agriculture, Irrigation and Water Development, P.O. Box 30779, Lilongwe 3, MALAWI

mwatts@bgs.ac.uk; +44 (0) 1159363042

\section{Acknowledgments}

EJMJ, MRB, ADCC, ELA, SDY and MJW conceived the study; EJMJ and ADCC collected samples; MJW and EMH analysed the samples; EJMJ drafted the text and figures; all authors read, contributed to and approved the final manuscript.

EJMJ's studentship was funded by the University of Nottingham, UK and the British Geological Survey.

The authors would like to thank Paul Williams (Queens University Belfast) and Andy Meharg (University of Aberdeen) for providing valuable advice, references and supplementary data during the manuscript drafting. 


\begin{abstract}
Widespread potential dietary deficiencies of calcium $(\mathrm{Ca})$, iron $(\mathrm{Fe})$, iodine (I), selenium $(\mathrm{Se})$ and zinc (Zn) have been identified in Malawi. Several deficiencies are likely to be compounded by high phytic acid (PA) consumption. Rice (Oryza sativa) is commonly consumed in some Malawian populations and its mineral micronutrient content is important for food security. The considerable irrigation requirements and flooded conditions of paddy soils can also introduce or mobilise potentially toxic elements including arsenic (As), cadmium $(\mathrm{Cd})$ and lead $(\mathrm{Pb})$. The aim of this study was to determine the mineral composition of rice sampled from farmers' fields and markets in Malawi.
\end{abstract}

Rice was sampled from 18 Extension Planning Areas across Malawi with 21 white (i.e. polished) and 33 brown samples collected. Elemental composition was determined by inductively-coupled plasmamass spectrometry (ICP-MS). Arsenic speciation was performed using high performance liquid chromatography (HPLC)-ICP-MS. Concentration of PA was determined using a PA-total phosphorus assay.

Median total concentrations ( $\mathrm{mg} \mathrm{kg}^{-1}$, dry-weight) of elements important for human nutrition in brown and white rice, respectively, were: $\mathrm{Ca}=66.5$ and 37.8; $\mathrm{Cu}=3.65$ and $2.49 ; \mathrm{Fe}=22.1$ and $7.2 ; \mathrm{I}=$ 0.006 and $<0.005 ; \mathrm{Mg}=1130$ and $265 ; \mathrm{Mn}=18.2$ and 9.6; $\mathrm{Se}=0.025$ and $0.028 ;$ and $\mathrm{Zn}=17.0$ and 14.4. In brown and white rice samples, respectively, median PA concentrations were 5,438 and 1,906 $\mathrm{mg} \mathrm{kg}{ }^{-1}$ and median PA:Zn molar ratios were 29 and 13 . Concentrations of potentially toxic elements (mg kg-1 ${ }^{-1}$ dry-weight) in brown and white rice samples, respectively, were: $\mathrm{As}=0.030$ and 0.006; Cd $=<0.002$ and $0.006 ; \mathrm{Pb}=0.008$ and 0.008 . Approximately $95 \%$ of As was found to be inorganic As, where this could be quantified.

Malawian rice, like the more widely consumed staple grain maize, contains inadequate $\mathrm{Ca}$, I, Se or $\mathrm{Zn}$ to meet dietary requirements. Biofortification strategies could significantly increase $\mathrm{Se}$ and $\mathrm{Zn}$ concentrations and require further investigation. Concentrations of $\mathrm{Fe}$ in rice grain varied greatly and 
this was likely due to contamination of rice samples with soil. Risk of $\mathrm{As}, \mathrm{Cd}$ or $\mathrm{Pb}$ toxicity due to rice consumption in Malawi appears to be minimal.

\section{Keywords}

Arsenic; Micronutrient deficiencies; Phytic acid; Rice; Selenium; Zinc.

\section{Background}

Micronutrients including the elements calcium $(\mathrm{Ca})$, copper $(\mathrm{Cu})$, iron $(\mathrm{Fe})$, iodine $(\mathrm{I})$, magnesium $(\mathrm{Mg})$, manganese $(\mathrm{Mn})$, selenium $(\mathrm{Se})$ and zinc $(\mathrm{Zn})$ are essential components of a healthy diet. Dietary deficiencies of $\mathrm{Ca}$, Se and $\mathrm{Zn}$ are widespread in Malawi and likely to cause a significant disease burden (Stein 2010; Chilimba et al. 2011; Broadley et al. 2012; Wessells and Brown 2012; Hurst et al. 2013; Siyame et al. 2013; Verduzco-Gallo et al. 2014; Joy et al. 2014; Joy et al. 2015b; Kumssa et al. 2015). In addition, deficiency of I is likely to affect individuals not consuming adequately iodised salt (Kalimbira et al. 2005; Joy et al. 2015b; Watts et al. 2015) and anaemia is widespread, which may be partly due to dietary Fe deficiency (WHO 2008). In contrast, dietary deficiencies of $\mathrm{Cu}$ and $\mathrm{Mg}$ are unlikely to affect the majority of the population of Malawi due to adequate supplies via the staple crop maize. However, phytic acid (PA), found in high concentrations in cereal grains, chelates metal ions including $\mathrm{Mg}, \mathrm{Ca}, \mathrm{Fe}$ and $\mathrm{Zn}$, thus reducing bioavailability (Konietzny et al. 2003; Bohn et al. 2004; Fredlund et al. 2006).

Rice (Oryza sativa) is important for food security in Malawi. At a national level, there was $13 \mathrm{~g}$ capita $^{-1} \mathrm{~d}^{-1}$ of rice available for consumption in 2011 of which $>99 \%$ was produced domestically (FAO 2015). This compares to 360,8 and 5 g capita $^{-1} \mathrm{~d}^{-1}$ of maize, sorghum and millet, respectively (FAO 2015). Rice consumption was recorded using $7 \mathrm{~d}$ dietary recall in $>30 \%$ of households in the Third Integrated Household Survey (NSO 2012; Joy et al. 2015b). Among households consuming rice, mean consumption was $67 \mathrm{~g}$ capita ${ }^{-1} \mathrm{~d}^{-1}$. Rice is also exported from Malawi with 1,841 tonnes 
exported in 2013 (FAO 2015). Thus, the nutrient composition of rice grown in Malawi is an important consideration for public health.

Rice is one of the focus crops for the HarvestPlus biofortification programme with target concentrations of $\mathrm{Fe}$ and $\mathrm{Zn}$ in polished white grain of 15 and $28 \mathrm{mg} \mathrm{kg}^{-1}$ dry weight (DW), respectively (Bouis and Welch 2010). Biofortification via breeding or fertilisers could be a highly cost-effective strategy to address widespread deficiencies of micronutrients such as $\mathrm{Zn}$ in low income countries, including sub-Saharan Africa (Stein et al. 2007; Harris et al. 2008; White and Broadley 2009; Joy et al. 2015c). Quantifying micronutrient intakes in typical Malawian diets may also inform food fortification strategies such as salt iodisation. Notably, there is evidence of inadequate and excessive intakes of I in Malawi (Watts et al. 2015).

The flooded state of paddy soils affects element mobility and therefore grain element concentrations. Reducing conditions due to flooding lead to an increase in soil $\mathrm{pH}$ and a decrease in the phytoavailability of Zn, contributing to Zn deficiencies in rice plants and humans (Alloway 2009). Conversely, reducing conditions increase the phytoavailability of As, an element which is highly toxic to humans in inorganic forms (WHO 2001). Under aerobic soil conditions As is mainly bound to clay minerals, Fe and Mn oxides or organic substrates in the form of arsenate ( $\left.\mathrm{As}^{\mathrm{V}}\right)$ (Stroud et al. 2011). Under anaerobic conditions, the dominant form of soluble As is typically arsenite (As $\left.{ }^{\mathrm{III}}\right)$ which is highly mobile. Problems of As toxicity generally occur over sedimentary rocks, which may have greater As concentrations (range 1.7-400 mg kg-1) than igneous rocks (range 1.5-3.0 mg kg-1 ; Smith et al., 1998). High As concentrations in groundwater can lead to accumulation of As in paddy soils through irrigation (Duxbury et al. 2003). Irrigation water can also contaminate soils with metals including cadmium $(\mathrm{Cd})$ and lead $(\mathrm{Pb})$. Whereas As in irrigation water is typically geogenic, $\mathrm{Cd}$ and $\mathrm{Pb}$ are typically anthropogenic and potentially toxic levels have been reported in rice grown downstream of mine tailings in China (Yang et al. 2004; Yang et al. 2006). Like Zn, the phytoavailability of $\mathrm{Cd}$ is low in anaerobic soil conditions and concentrations in rice depend on water management strategies (Daum et al. 2002). 
In the present study, elemental concentrations are reported in 54 rice samples grown in the major production areas of Malawi, thus extending the number of samples and area covered that was reported previously $(n=21$; Joy et al., 2015a). Furthermore, dietary exposures are quantified for elements important for human nutrition and those that are potentially toxic.

\section{Materials and methods}

\section{Sampling locations and sample preparation}

Samples of rice grain $(n=54)$ were collected across Malawi from 18 Extension Planning Areas (EPAs; Figure 1). The areas sampled included: smallholder production near Karonga; governmentsponsored irrigation schemes near Nkhata Bay and Salima; smallholder production near Lake Chilwa; and smallholder and irrigation schemes in the Shire River basin. Whole grain samples were collected from farmers' fields and household stores. The husks of whole grain samples were removed using a mortar and pestle but these samples were not polished thus leaving the bran largely intact, i.e. brown rice. In addition, polished grain samples were collected from rice mills, i.e. white rice.

\section{Elemental analysis}

Grain samples were milled to $<40 \mu \mathrm{m}$ in an agate ball mill and $0.5 \mathrm{~g}$ of sample was digested in $10 \mathrm{~mL}$ $\mathrm{HNO}_{3}$ plus $1 \mathrm{~mL} \mathrm{H}_{2} \mathrm{O}_{2}$ mixed solution in a closed vessel microwave heating system (MARS Xpress, CEM Microwave Technology Ltd, Buckingham, UK). Subsequent total elemental analysis was carried out by inductively coupled plasma mass spectrometry (ICP-MS; Agilent 7500cx, Santa Clara, USA) using (i) collision cell mode (helium gas) for $\mathrm{Li}, \mathrm{Be}, \mathrm{B}, \mathrm{Na}, \mathrm{Mg}, \mathrm{Al}, \mathrm{P}, \mathrm{S}, \mathrm{K}, \mathrm{Ca}, \mathrm{Ti}, \mathrm{V}, \mathrm{Cr}, \mathrm{Mn}$, $\mathrm{Fe}, \mathrm{Co}, \mathrm{Ni}, \mathrm{Cu}, \mathrm{Zn}, \mathrm{Ga}, \mathrm{As}, \mathrm{Rb}, \mathrm{Sr}, \mathrm{Y}, \mathrm{Zr}, \mathrm{Nb}, \mathrm{Mo}, \mathrm{Ag}, \mathrm{Cd}, \mathrm{Sn}, \mathrm{Sb}, \mathrm{Cs}, \mathrm{Ba}, \mathrm{La}, \mathrm{Ce}, \mathrm{Pr}, \mathrm{Nd}, \mathrm{Sm}, \mathrm{Eu}$, Gd, Tb, Dy, Ho, Er, Tm, Yb, Lu, Hf, Ta, W, Tl, Pb, Bi, Th and U; and (ii) hydrogen reaction cell mode for Si and Se (Hamilton et al. 2015; Joy et al. 2015). Iodine analyses were undertaken separately owing to the requirement for an alkaline extraction with tetramethylammonium hydroxide (TMAH). Milled samples ( $0.5 \mathrm{~g}$ ) were extracted using $5 \mathrm{~mL}$ of $5 \%$ TMAH using the same closed 
vessel microwave heating system, with a final matrix of $0.5 \%$ TMAH analysed by ICP-MS, as described previously (Watts et al. 2015; Zia et al. 2015).

\section{Arsenic speciation}

For samples with total As concentration $>0.020 \mathrm{mg} \mathrm{kg}^{-1}$, the concentrations of the inorganic forms of As $\left(\mathrm{As}^{\mathrm{III}}\right.$ and $\left.\mathrm{AsO}_{4}{ }^{3-}\right)$ and organic forms (monomethylarsonic acid (MMA), dimethylarsenic acid (DMA) and arsenobetaine) were determined. Methods were as described in Watts et al. (2008) and Al-Rmalli et al. (2012). Briefly, speciation was achieved by using a quaternary pump (GP50-2 HPLC Pump) and an AS-50 Autosampler, (Dionex, Sunnyvale, USA) and measurement of concentrations was by ICP-MS (Agilent 7500cx). The limits of detection (LOD) for total As concentration were $0.01-0.001 \mathrm{mg} \mathrm{kg}^{-1}$ depending on the analytical run, whilst for all samples the LOD was $<0.001 \mathrm{mg}$ $\mathrm{kg}^{-1}$ for $\mathrm{As}^{\mathrm{III}}, \mathrm{MMA}, \mathrm{DMA}$ and arsenobetaine and $<0.004 \mathrm{mg} \mathrm{kg}^{-1}$ for $\mathrm{As}^{\mathrm{V}}$.

\section{Phytic acid determination}

Phytic acid was measured as described by Reason et al. (2015) using a PA-total phosphorus assay kit (Megazyme, County Wicklow, Ireland), comprising of an ammonium molybdate, $\mathrm{H}_{2} \mathrm{SO}_{4} /$ ascorbic acid complexation to form molybdenum blue. The concentration of molybdenum blue is directly proportional to the concentration of inorganic phosphate separated from the extracted PA and quantifiable by ultraviolet-visible spectroscopy at $655 \mathrm{~nm}$ (Lambda 35, PerkinElmer, Waltham, MA, USA).

\section{Dietary element supplies via rice}

The mean dietary supply of elements via rice was quantified among households consuming rice from a recent nationally-representative household consumption survey (NSO, 2012; Joy et al., 2015b). Dietary element supplies were quantified as the product of mean rice consumption $\left(67 \mathrm{~g} \mathrm{capita}^{-1} \mathrm{~d}^{-1}\right)$ and median elemental concentration in white rice samples, as rice is typically milled prior to consumption in Malawi. Estimated mean element consumptions are compared to Recommended Nutrient Intakes (RNIs; WHO and FAO 2004) and Recommended Dietary Allowances (RDAs; IOM 2000, IOM 2002), 
i.e. the level of intake adequate for $97.5 \%$ of healthy individuals in an age- and sex-specific population group. Maximum dietary supply of potentially toxic elements was calculated as consumption of $200 \mathrm{~g}$ capita $^{-1} \mathrm{~d}^{-1}$ of rice combined with maximum elemental concentrations in white rice. Risk was assessed using a hazard quotient, the ratio between average daily consumption and oral reference dose which is the daily exposure to individuals that is likely to cause no deleterious effects to human health over a lifetime.

\section{Quality control}

Samples were run alongside three certified reference materials (CRMs) with mean accuracy $>80 \%$ for As, $>98 \%$ for $\mathrm{Ca},>88 \%$ for $\mathrm{Cd},>89 \%$ for $\mathrm{Fe},>96 \%$ for $\mathrm{Mg},>97 \%$ for $\mathrm{Mn},>96 \%$ for $\mathrm{Pb},>62 \%$ for Se and $>86 \%$ for $\mathrm{Zn}$ (Online Resource 1). The Se concentrations for the CRMs were close to the method LOD, resulting in a slight overestimation of the Se recovery (Online Resource 1). It is possible that although the CRMs used were not directly matrix matched, the Se concentrations for rice samples were slightly overestimated. Phytic acid concentration was determined in one reference material with mean \pm standard deviation (SD) accuracy of $87 \pm 5 \%$ (Online Resource 1). For As speciation, a series of blank solutions (deionised water) and calibration standards (1-50 $\left.\mu \mathrm{g} \mathrm{L}^{-1} \mathrm{As}\right)$ for each of the five As species were utilised within each analytical run. Mean \pm SD recovery of As species as a proportion of total As concentration was $88 \pm 9 \%$ (Online Resource 2). For further quality assessment, As ${ }^{\mathrm{III}}$ was spiked into separate vessels at 5 and $40 \mu \mathrm{g} \mathrm{L}^{-1}$ and subjected to the microwave procedure to evaluate any conversion of $\mathrm{As}^{\mathrm{III}}$ to $\mathrm{As}^{\mathrm{V}}$. Recoveries of 105 and $108 \%$ indicated that this was not a problem.

\section{Results and discussion}

\section{Elemental composition of rice grains}

All concentrations are reported on a dry weight (DW) basis. Summary statistics are presented in Table 1 and raw data in Online Resource 3. Elemental concentrations are compared with data from rice grown in Tanzania (Mohammed and Spyrou 2009), a neighbouring country with a similar scale of rice 
production as Malawi (FAO 2015). Concentrations of Se and As are also compared to data from major global rice production areas as there are limited data for these elements and their uptake by plants is strongly controlled by local geochemical conditions, resulting in wide variation in plant concentrations. Results of As speciation and phytic acid concentrations are presented in Online Resources 2 and 4.

\section{Elements important for human nutrition}

\section{Calcium}

The mean and median Ca concentrations in brown rice samples were 72.6 and $66.5 \mathrm{mg} \mathrm{kg}^{-1}$ and in white rice samples were 37.7 and $37.8 \mathrm{mg} \mathrm{kg}^{-1}$, respectively (Table 1). Mean dietary supply of Ca from rice in Malawi among rice-consuming households was $2.53 \mathrm{mg} \mathrm{capita}^{-1} \mathrm{~d}^{-1}$ (Table 1). By comparison, the RNI for adult males aged 19-65 eating a cereal-dominated diet is 750 mg capita $^{-1} \mathrm{~d}^{-1}$ (WHO and FAO 2004). The mean \pm standard error (SE) concentration of $\mathrm{Ca}$ in rice grown in Tanzania was $57 \pm 5 \mathrm{mg} \mathrm{kg}^{-1}$ (Mohammed and Spyrou 2009).

\section{Copper}

The mean and median $\mathrm{Cu}$ concentrations in brown rice samples were 5.52 and $3.65 \mathrm{mg} \mathrm{kg}^{-1}$ and in white rice samples were 3.09 and $2.49 \mathrm{mg} \mathrm{kg}^{-1}$, respectively (Table 1). Mean dietary supply of $\mathrm{Cu}$ from rice among rice-consuming households was $0.17 \mathrm{mg} \mathrm{capita}^{-1} \mathrm{~d}^{-1}$ (Table 1). By comparison, the RDA of $\mathrm{Cu}$ for adults aged $19-65$ is $0.9 \mathrm{mg}_{\text {capita }} \mathrm{d}^{-1} \mathrm{~d}^{-1}$ (IOM 2000). The mean $\pm \mathrm{SE}$ concentration of $\mathrm{Cu}$ in rice grown in Tanzania was $3.5 \pm 0.7 \mathrm{mg} \mathrm{kg}^{-1}$ (Mohammed and Spyrou 2009).

\section{Iron}

The mean and median Fe concentrations in brown rice samples were 32.0 and $22.1 \mathrm{mg} \mathrm{kg}^{-1}$ and in white rice samples were 7.9 and $7.2 \mathrm{mg} \mathrm{kg}^{-1}$, respectively (Table 1). Mean dietary supply of Fe from rice among rice-consuming households was $0.5 \mathrm{mg}_{\text {capita }}{ }^{-1} \mathrm{~d}^{-1}$ (Table 1). By comparison, the RNIs for adult males and females of reproductive age, respectively, are 13.7 and $29.4 \mathrm{mg} \mathrm{capita}^{-1} \mathrm{~d}^{-1}$ when 
consuming a cereal-dominated diet (WHO and FAO 2004). The Fe concentration in 20 of 21 samples of white rice was $<15 \mathrm{mg} \mathrm{kg}^{-1}$, the HarvestPlus breeding target for polished rice. The mean $\pm \mathrm{SE}$ concentration of Fe in rice grown in Tanzania was $23 \pm 2 \mathrm{mg} \mathrm{kg}^{-1}$ (Mohammed and Spyrou 2009).

The concentration of Fe is typically $\sim 3$ orders of magnitude greater in soils than in plant tissue. Thus, the Fe concentration of cereal grains is greatly affected by even minor contamination with soil dust. This can be detected and quantified using vanadium (V) concentration as a proxy (Joy et al. 2015a). The situation is possibly more complicated for flooded soils because anaerobic mobilization of $\mathrm{Fe}^{\mathrm{II}}$ from $\mathrm{Fe}^{\mathrm{III}}$ oxides is also likely to solubilize both adsorbed vanadate anions $\left(\mathrm{VO}_{4}{ }^{3-}\right)$ and vanadyl cations $\left(\mathrm{VO}^{2+}\right)$. Nevertheless it still seems more likely that a strong correlation between plant $\mathrm{Fe}$ and $\mathrm{V}$ indicates extraneous contamination with $\mathrm{V}^{3+}$-substituted Fe oxide particles rather than coincidental uptake by plant roots and systemic transfer to rice grains. Indeed, there was a strong correlation between $\mathrm{Fe}$ and $\mathrm{V}$ concentrations in brown and white rice samples, i.e. $\mathrm{r}(19)=0.62 ; \mathrm{p}=0.003$ (Figure 2). The strong correlation between titanium and Fe concentrations is also indicative of soil contamination, i.e. $\mathrm{r}(19)=0.85, \mathrm{p}<0.00001$. In Malawi, rice is typically threshed in the field by hand and this would allow contamination of the grain with soil. Polishing the rice grain decreased Fe and V concentrations by $\sim 3$-fold (Table 1; Figure 2) but the correlation between Fe and V concentrations remained strong. Thus, it is likely that a significant proportion of Fe in both white and brown rice samples was from extraneous soil dust and this might mask variation in endogenous Fe due to varietal factors or growing conditions, a finding that is highly relevant for breeding studies. In addition, further research is required to determine whether cooking leads to removal of the soil dust and, if not fully, to quantify the bioavailability of Fe in contaminant soil (Gibson et al. 2015).

\section{Iodine}

The mean and median I concentrations in brown rice samples were 0.007 and $0.006 \mathrm{mg} \mathrm{kg}^{-1}$ and in white rice samples were $<0.005 \mathrm{mg} \mathrm{kg}^{-1}$ (Table 1). Mean dietary supply of I from rice among riceconsuming households was $<0.4 \mu \mathrm{g}$ capita $^{-1} \mathrm{~d}^{-1}$ (Table 1). By comparison, the RNI for adult males and females is $150 \mu \mathrm{g}$ capita $^{-1} \mathrm{~d}^{-1}$ (WHO and FAO 2004). Iodine concentrations in the above-ground 
components of crops are typically low in non-coastal environments (Fuge and Johnson 1986) and dietary I supply in Malawi is largely dependent on iodised salt (Watts et al 2015; Joy et al 2015b).

\section{Magnesium}

The mean and median $\mathrm{Mg}$ concentrations in brown rice samples were 1140 and $1130 \mathrm{mg} \mathrm{kg}^{-1}$ and in white rice samples were 259 and $265 \mathrm{mg} \mathrm{kg}^{-1}$, respectively (Table 1). Mean dietary supply of $\mathrm{Mg}$ from rice among rice-consuming households was $17.8 \mathrm{mg} \mathrm{capita}^{-1} \mathrm{~d}^{-1}$ (Table 1). By comparison, the RNI for adult males is $220 \mathrm{mg}_{\text {capita }} \mathrm{d}^{-1}$ (WHO and FAO 2004). The mean $\pm \mathrm{SE}$ concentration of $\mathrm{Mg}$ in rice grown in Tanzania was $643 \pm 41 \mathrm{mg} \mathrm{kg}^{-1}$ (Mohammed and Spyrou 2009).

\section{Manganese}

The mean and median Mn concentrations in brown rice samples were 20.1 and $18.2 \mathrm{mg} \mathrm{kg}^{-1}$ and in white rice samples were 9.4 and $9.6 \mathrm{mg} \mathrm{kg}^{-1}$, respectively (Table 1). Mean dietary supply of Mn from rice among rice-consuming households was $0.64 \mathrm{mg} \mathrm{capita}^{-1} \mathrm{~d}^{-1}$ (Table 1). By comparison, the RDA for adult males is $2.3 \mathrm{mg}$ capita $^{-1} \mathrm{~d}^{-1}$ (IOM 2000). The mean $\pm \mathrm{SE}$ concentration of $\mathrm{Mn}$ in rice grown in Tanzania was $16 \pm 1 \mathrm{mg} \mathrm{kg}^{-1}$ (Mohammed and Spyrou 2009).

\section{Selenium}

The mean and median Se concentrations in brown rice samples were 0.041 and $0.025 \mathrm{mg} \mathrm{kg}^{-1}$ and in white rice samples were 0.040 and $0.028 \mathrm{mg} \mathrm{kg}^{-1}$, respectively (Table 1). Mean dietary supply of Se from rice among rice-consuming households was $<2 \mu$ capita $^{-1} \mathrm{~d}^{-1}$ (Table 1). By comparison, the RNI for adults is $55 \mu \mathrm{g}$ capita $^{-1} \mathrm{~d}^{-1}$ (IOM 2002). Low concentrations of Se in rice grain have been reported in a market-based survey in Egypt (median $=0.006 \mathrm{mg} \mathrm{kg}^{-1} ; \mathrm{n}=102$; Williams et al. 2009) and Nigeria (mean $=0.003 \mathrm{mg} \mathrm{kg}^{-1} ; \mathrm{n}=23$; Adedire et al. 2015) and in brown rice grown in Madagascar (median $=0.039 \mathrm{mg} \mathrm{kg}^{-1} ; \mathrm{n}=51$; Rothenberg et al. 2015) while Adomako et al. (2011) reported mean Se concentrations of 0.08 and $0.09 \mathrm{mg} \mathrm{kg}^{-1}$ in brown and white rice grown in Ghana (Figure 3). In comparison, the median Se concentration in rice grain grown in the USA was 0.176 $\mathrm{mg} \mathrm{kg}^{-1}(\mathrm{n}=161)$ while Se in rice grain from China ranged from $0.002-1.370 \mathrm{mg} \mathrm{kg}^{-1}(\mathrm{n}=523)$ 
(Williams et al. 2009). The mean concentration of Se in medium-grain white rice available commercially in the USA was $0.173 \mathrm{mg} \mathrm{kg}^{-1}$ (USDA-ARS 2013).

The Se concentration in one sample of brown rice was $0.300 \mathrm{mg} \mathrm{kg}^{-1}$, i.e. $>2$-fold greater than the next highest concentration. The sample was grown at an irrigation scheme in the Shire River basin where Chilimba et al. (2011) demonstrated $\sim 10$-fold greater transfer of Se from Eutric Vertisols to maize grain compared to typical low-pH soils in Malawi. Genotypic differences may have also contributed to variation in grain Se concentrations although this was not investigated in the present study.

Notably, greater Se concentrations were reported in the grain of aromatic rice than non-aromatic rice from an area of Bangladesh where typical soils have low plant-available Se (Al-Rmalli et al. 2012). Further sampling is required to determine the genotypic variation in Se concentrations in Malawian rice.

Zinc

The mean and median $\mathrm{Zn}$ concentrations in brown rice samples were 18.8 and $17.0 \mathrm{mg} \mathrm{kg}^{-1}$ and in white rice samples were 14.7 and $14.4 \mathrm{mg} \mathrm{kg}^{-1}$, respectively (Table 1). Mean dietary supply of Zn from rice among rice-consuming households was $1.0 \mathrm{mg} \mathrm{capita}^{-1} \mathrm{~d}^{-1}$ (Table 1). By comparison, the RNI for an adult male eating a cereal-dominated diet is $14 \mathrm{mg}_{\text {capita }}{ }^{-1} \mathrm{~d}^{-1}$ (WHO and FAO 2004). The Zn concentration in all samples of white rice was $<28 \mathrm{mg} \mathrm{kg}^{-1}$, the HarvestPlus breeding target for polished rice. The mean $\pm \mathrm{SE}$ concentration of $\mathrm{Zn}$ in rice grown in Tanzania was $28 \pm 2 \mathrm{mg} \mathrm{kg}^{-1}$ (Mohammed and Spyrou 2009).

\section{Phytic acid}

Concentrations of PA are important in determining the bioavailability of metal ions including $\mathrm{Ca}, \mathrm{Fe}$, Mg, Mn and Zn (Gibson 2010). The PA concentration was $\sim 3$-fold greater in brown than white rice samples, with median concentrations of 5,440 and 1,910 $\mathrm{mg} \mathrm{kg}^{-1}$, respectively (Table 1; Online Resource 4). Median PA:element molar ratios in brown rice were $\mathrm{Ca}(76), \mathrm{Fe}(23), \mathrm{Mg}(0.18), \mathrm{Mn}$ (25.5) and $\mathrm{Zn}$ (29) and in white rice were $\mathrm{Ca}$ (27), $\mathrm{Fe}$ (23), $\mathrm{Mg}$ (0.24), $\mathrm{Mn}$ (15.9) and $\mathrm{Zn}$ (13). Thus, 
removal of the bran is likely to increase the bioavailability of $\mathrm{Ca}, \mathrm{Mn}$ and $\mathrm{Zn}$, reduce the bioavailability of $\mathrm{Mg}$ and have little impact of the bioavailability of Fe (Online Resource 4).

\section{Potentially toxic elements}

Arsenic

The mean and median concentrations of total As in brown rice samples were 0.040 and $0.030 \mathrm{mg} \mathrm{kg}^{-1}$, respectively, and in white rice samples was 0.010 and $0.006 \mathrm{mg} \mathrm{kg}^{-1}$, respectively (Table 1). This is low in comparison to white rice grown in other countries, i.e. (mean $\pm \mathrm{SD}, \mathrm{mg} \mathrm{kg}^{-1}$ ): $\mathrm{USA}=0.23 \pm$ 0.07 ; Italy $=0.19 \pm 0.05$; China $0.16 \pm 0.14$; Thailand $0.12 \pm 0.03$; Bangladesh $0.10 \pm 0.07$; and India $0.06 \pm 0.04$ (Figure 4; Meharg et al. 2009). Arsenic concentration in Malawian rice was also lower than the mean $\pm \mathrm{SE}$ reported in Ghanaian white rice $\left(0.09 \pm 0.01 \mathrm{mg} \mathrm{kg}^{-1} ; \mathrm{n}=19\right)$ and brown rice $\left(0.11 \pm 0.02 \mathrm{mg} \mathrm{kg}^{-1} ; \mathrm{n}=29\right.$; Adomako et al. 2011) and Madagascan brown rice (median $=0.16 \mathrm{mg}$ $\mathrm{kg}^{-1} ; \mathrm{n}=51$; Rothenberg). In a global study, the US Food and Drug Administration (2013) reported a median (Q1, Q3) As concentration in milled rice of $0.186(0.118,0.240 ; \mathrm{n}=314) \mathrm{mg} \mathrm{kg}^{-1}$. The greatest total As concentrations were found in medium grain rice from Texas, USA, with median (Q1, Q3) concentrations of $0.630(0.615,0.654 ; \mathrm{n}=9) \mathrm{mg} \mathrm{kg}^{-1}$ while Pinson et al. (2014) reported a mean \pm SD concentration of $0.945 \pm 0.312 \mathrm{mg} \mathrm{kg}^{-1}$ in brown rice grown in flooded conditions in Texas, USA (Figure 4). Al-Rmalli et al. (2012) reported a mean \pm SD concentration of total As in nonaromatic rice from Bangladesh of $0.081 \pm 0.040 \mathrm{mg} \mathrm{kg}^{-1}$ but a lower concentration in aromatic rice of $0.048 \pm 0.043 \mathrm{mg} \mathrm{kg}^{-1}$.

Arsenic speciation was conducted on 17 samples of brown rice with total As concentrations $>0.02$ $\mathrm{mg} \mathrm{kg}^{-1}$; speciation was not conducted for white rice samples due to the very low total As concentrations. The mean and median concentrations of inorganic As (i-As) were 0.060 and $0.066 \mathrm{mg}$ $\mathrm{kg}^{-1}$ which is low compared to white rice samples from most other countries, despite being measured on the 17 samples with highest As concentration in this study, i.e. (mean $\pm \mathrm{SD}, \mathrm{mg} \mathrm{kg}^{-1}$ ): China $0.14 \pm$ 0.05; Italy $0.12 \pm 0.03$; USA $0.09 \pm 0.02$; Bangladesh $0.08 \pm 0.06$; Thailand $0.08 \pm 0.01$; and India 
$0.05 \pm 0.03$ (Williams et al. 2005; Meharg et al. 2009). Adomako et al. (2011) reported a mean i-As concentration of $0.091 \mathrm{mg} \mathrm{kg}^{-1}$ in white rice grown in Ghana while a median i-As concentration of $0.128 \mathrm{mg} \mathrm{kg}^{-1}(\mathrm{n}=44)$ was reported in long grain rice grown in the USA (US FDA 2013). In the present study, $\sim 95 \%$ of total As was i-As. Adomako et al. (2011) reported a similarly high proportion of i-As in rice grown in Ghana (83\%). By comparison, Pinson et al. (2014) reported $\sim$ half of total As was i-As in rice samples grown in Texas. Al-Rmalli et al. (2012) reported that $40-92 \%$ of total As was i-As in Bangladeshi rice while Williams et al. (2005) reported 80\% i-As in Bangladeshi rice.

Rice may be a significant source of As exposure in some contexts with consequences for cancer risk (Mondal and Polya 2008; Banerjee et al. 2013). The oral reference dose is set at $3^{*} 10^{-4} \mathrm{mg} \mathrm{kg}^{-1}$ of body weight for i-As (US EPA 1998). The low concentrations of total As in white rice samples from Malawi restricted the ability to conduct As speciation. However, even if all the As in white rice was iAs, consumption of $0.2 \mathrm{~kg} \mathrm{~d}^{-1} \mathrm{DW}$ would provide $\sim 1.7 * 10^{-5} \mathrm{mg}$ of $\mathrm{i}-\mathrm{As} \mathrm{kg}^{-1}$ of body weight (Online Resource 5). Thus, on the basis of sample data reported in the present study, consumption of rice grown in Malawi is unlikely to pose a risk of As toxicity.

\section{Cadmium}

The mean and median Cd concentrations in brown rice samples were 0.006 and $<0.002 \mathrm{mg} \mathrm{kg}^{-1}$ and in white rice samples were 0.009 and $0.006 \mathrm{mg} \mathrm{kg}^{-1}$, respectively (Table 1). Low concentration of Cd is consistent with data reported globally from flooded rice production with negligible anthropogenic $\mathrm{Cd}$ in irrigation water, for example mean of 0.013 and $0.011 \mathrm{mg} \mathrm{kg}^{-1}$ in brown and white rice, respectively, grown in Ghana (Adomako et al. 2011) and median of $0.0024 \mathrm{mg} \mathrm{kg}^{-1}$ in brown rice grown in Madagascar (Rothenberg et al. 2015). Yang et al. (2006) reported a mean $\pm \mathrm{SD}$ Cd concentration of $0.24 \pm 0.16 \mathrm{mg} \mathrm{kg}^{-1}$ in unmilled rice from paddy fields in southern China where irrigation water was contaminated by mine tailings.

The reference dose of Cd is $1 * 10^{-3} \mathrm{mg} \mathrm{kg}^{-1}$ body weight (US EPA 1994). Consumption of $0.2 \mathrm{~kg} \mathrm{~d}^{-1}$ DW of Malawian rice would supply $5.7 * 10^{-6} \mathrm{mg}$ of $\mathrm{Cd} \mathrm{kg}^{-1}$ of body weight (Online Resource 5). 
Thus, on the basis of sample data reported in the present study, consumption of rice grown in Malawi is unlikely to pose a risk of Cd toxicity.

\section{Lead}

The mean and median $\mathrm{Pb}$ concentrations in brown rice samples were 0.095 and $0.008 \mathrm{mg} \mathrm{kg}^{-1}$ and in white rice samples were 0.011 and $0.008 \mathrm{mg} \mathrm{kg}^{-1}$, respectively (Table 1 ). Low $\mathrm{Pb}$ concentration is consistent with data reported globally from flooded rice production with negligible anthropogenic $\mathrm{Pb}$ in irrigation water. For example, Adomako et al. (2011) reported mean $\pm \mathrm{SE} \mathrm{Pb}$ concentrations of $0.043 \pm 0.007 \mathrm{mg} \mathrm{kg}^{-1}$ in brown rice $(\mathrm{n}=19)$ and $0.015 \pm 0.004 \mathrm{mg} \mathrm{kg}^{-1}$ in white rice $(\mathrm{n}=29)$ grown in Ghana. By comparison, Yang et al. (2004) reported a mean $\pm \mathrm{SE}$ Pb concentration of $4.67 \pm 3.30$ $\mathrm{mg} \mathrm{kg}^{-1}$ in brown rice from paddy fields in southern China where irrigation water was contaminated by mine tailings.

\section{Conclusions}

The present study reported elemental concentrations in white and brown rice grain grown in Malawi. Concentrations of $\mathrm{Ca}$, I, Se or $\mathrm{Zn}$ were low relative to dietary requirements. However, biofortification strategies could increase $\mathrm{Se}$ and $\mathrm{Zn}$ concentrations in the grain and this requires further investigation. Concentrations of $\mathrm{Fe}$ in rice grain varied greatly and this was likely influenced by contamination of rice samples with soil as demonstrated by the strong correlation between concentrations of $\mathrm{Fe}$ and $\mathrm{V}$. The concentration of PA was $\sim 3$-fold greater in brown than white rice and the median PA:Zn molar ratio was 29 in brown rice samples compared to 13 in white rice. Thus, the bioavailablility of $\mathrm{Zn}$ is likely to be greater in white than brown rice, a finding that could be further investigated through simulated gastrointestinal digestion studies. Concentrations of $\mathrm{As}, \mathrm{Cd}$ and $\mathrm{Pb}$ are low, and are likely to represent minimal risk to human health based on the study data; thus, these study data present a largely positive story for Malawi. 


\section{References}

Adedire, C.O., Adeyemi, J.A., Paulelli, A.C., Martins-Junior, A.C., Ileke, K.D., Segura, F.R., et al. (2015). Toxic and essential elements in Nigerian rice and estimation of dietary intake through rice consumption. Food Additives \& Contaminants: Part B, 8(4), 271-276.

Adomako, E.E., Williams, P.N., Deacon, C., \& Meharg, A.A. (2011). Inorganic arsenic and trace elements in Ghanaian grain staples. Environmental Pollution, 159(10), 2435-2442.

Alloway, B.J. (2009). Soil factors associated with zinc deficiency in crops and humans. Environmental Geochemistry and Health, 31(5), 537-548.

Al-Rmalli, S.W., Jenkins, R.O., Watts, M.J., \& Haris, P.I. (2012). Reducing human exposure to arsenic, and simultaneously increasing selenium and zinc intake, by substituting non-aromatic rice with aromatic rice in the diet. Biomedical Spectroscopy and Imaging, 1(4), 365-381.

Banerjee, M., Banerjee, N., Bhattacharjee, P., Mondal, D., Lythgoe, P.R., Martinez, M., et al. (2013). High arsenic in rice is associated with elevated genotoxic effects in humans. Scientific Reports, $3(2195)$.

Bohn, T., Davidsson, L., Walczyk, T., \& Hurrell, R.F. (2004). Phytic acid added to white-wheat bread inhibits fractional apparent magnesium absorption in humans. American Journal of Clinical Nutrition, $79(3), 418-423$.

Bouis, H.E., \& Welch, R.M. (2010). Biofortification - a sustainable agricultural strategy for reducing micronutrient malnutrition in the global south. Crop Science, 50(S1), 20-32. 
Broadley, M.R., Chilimba, A.D.C., Joy, E.J.M., Young, S.D., Black, C.R., Ander, E.L., et al. (2012).

Dietary requirements for magnesium but not calcium are likely to be met in Malawi based on national food supply data. International Journal for Vitamin and Nutrition Research, 82(3), 192-199.

Chilimba, A.D.C., Young, S.D., Black, C.R., Rogerson, K.B., Ander, E.L., Watts, M.J., et al. (2011). Maize grain and soil surveys reveal suboptimal dietary selenium intake is widespread in Malawi. Scientific Reports, 1(72). doi:10.1038/srep00072.

Daum, D., Bogdan, K., Schenk, M.K., \& Merkel, D. (2002). Influence of the field water management on accumulation of arsenic and cadmium in paddy rice. In: W. J. Horst et al. (Eds.), Plant Nutrition (pp. 290-291). Dordrecht: Springer.

Duxbury, J.M., Mayer, A.B., Lauren, J.G., Hassan, N. (2003) Food chain aspects of arsenic contamination in Bangladesh: effects on quality and productivity of rice. Journal of Environmental Science and Health, Part A: Toxic/Hazardous Substances and Environmental Engineering, 38(1), 6169.

Food and Agriculture Organization of the United Nations, FAO (2015). FAOSTAT database. http://faostat3.fao.org/. Accessed June 2015.

Fredlund, K., Isaksson, M., Rossander-Hulthén, L., Almgren, A., \& Sandberg, A.S. (2006). Absorption of zinc and retention of calcium: Dose-dependent inhibition by phytate. Journal of Trace Elements in Medicine and Biology, 20(1), 49-57.

Fuge, R., \& Johnson, C.C. (1986). The geochemistry of iodine - a review. Environmental Geochemistry and Health, 8(2), 31-54. 
Gibson, R.S., Bailey, K.B., Gibbs, M., \& Ferguson, E.L. (2010). A review of phytate, iron, zinc, and calcium concentrations in plant-based complementary foods used in low-income countries and implications for bioavailability. Food and Nutrition Bulletin, 31(2 Suppl), S134-146.

Gibson, R.S., Wawer, A.A., Fairweather-Tait, S.J., Hurst, R., Young, S.D., Broadley, M.R., et al. (2015). Dietary iron intakes based on food composition data may underestimate the contribution of potentially exchangeable contaminant iron from soil. Journal of Food Composition and Analysis, 40, $19-23$.

Hamilton, E.M., Barlow, T.S., Gowing, C.J.B., \& Watts, M.J. (2015). Bioaccessibility performance data for fifty-seven elements in guidance material BGS 102. Microchemical Journal, 123, 131-138.

Harris, D., Rashid, A., Miraj, G., Arif, M., \& Yunas, M. (2008). On-farm seed priming with zinc in chickpea and wheat in Pakistan. Plant and Soil, 306(1), 3-10.

Hurst, R., Siyame, E.W.P., Young, S.D., Chilimba, A.D.C., Joy, E.J.M., Black, C.R., et al. (2013). Soil-type influences human selenium status and underlies widespread selenium deficiency risks in Malawi. Scientific Reports, 3(1425). doi:10.1038/srep01425.

Institute of Medicine of the National Academies, IOM (2000). Dietary Reference Intakes for vitamin A, vitamin K, arsenic, boron, chromium, copper, iodine, iron, manganese, molybdenum, nickel, silicon, vanadium and zinc. Washington DC: National Academies Press.

Institute of Medicine of the National Academies, IOM (2002). Dietary reference intakes for vitamin C, vitamin E, selenium, and carotenoids. Washington DC: National Academies Press.

Joy, E.J.M., Ander, E.L., Young, S.D., Black, C.R., Watts, M.J., Chilimba, A.D.C., et al. (2014). Dietary mineral supplies in Africa. Physiologia Plantarum, 151(3), 208-229. 
Joy, E.J.M., Broadley, M.R., Young, S.D., Black, C.R., Chilimba, A.D.C., Ander, E.L., et al. (2015a). Soil type influences crop mineral composition in Malawi. Science of the Total Environment, 505(1), $587-595$.

Joy, E.J.M., Kumssa, D.B., Broadley, M.R., Watts, M.J., Young, S.D., Chilimba, A.D.C., \& Ander, E.L. (2015b). Dietary mineral supplies in Malawi: spatial and socioeconomic assessment. $B M C$ nutrition, 1:42. doi:10.1186/s40795-015-0036-4.

Joy, E.J.M., Stein, A.J., Young, S.D., Ander, E.L., Watts, M.J., \& Broadley, M.R. (2015c). Zincenriched fertilisers as a potential public health intervention in Africa. Plant and Soil, 389(1), 1-24.

Kalimbira, A.A., Chilima, D.M., Mtimuni, B.M., \& Mvula, N. (2005). Knowledge and practices related to use of iodised salt among rural Malawian households. Bunda Journal of Agriculture, Environmental Science and Technology, 3, 73-82.

Konietzny, U., \& Greiner, R. (2003). Phytic acid: Nutritional impact. In: B. Caballero, L. Trugo, \& P. Finglas (Eds.), Encyclopaedia of food science and nutrition (pp. 4555-4563). London: Elsevier.

Kumssa, D.B., Joy, E.J.M., Ander, E.L., Watts, M.J., Young, S.D., Walker, S., \& Broadley, M.R. (2015). Dietary calcium and zinc deficiency risks are decreasing but remain prevalent. Scientific Reports, 5(10974). doi:10.1038/srep10974.

Meharg, A.A., Williams, P.N., Adomako, E., Lawgali, Y.Y., Deacon, C., Villada, A., et al. (2009). Geographical variation in total and inorganic arsenic content of polished (white) rice. Environmental Science \& Technology, 43(5), 1612-1617. 
Mohammed, N.K., \& Spyrou, N.M. (2009). Trace elemental analysis of rice grown in two regions of Tanzania. Journal of Radioanalytical and Nuclear Chemistry, 281, 79-82.

Mondal, D., \& Polya, D.A. (2008). Rice is a major exposure route for arsenic in Chakdaha block, Nadia district, West Bengal, India: A probabilistic risk assessment. Applied Geochemistry, 23(11), $2987-2998$.

National Statistics Office of the Republic of Malawi, NSO (2012). Malawi Third Integrated Household Survey (IHS3). NSO, Zomba, Malawi and World Bank Living Standards and Measurements Surveys. http://www.worldbank.org/en/research. Accessed September 2013.

Pinson, S.R.M., Tarpley, L., Yan, W., Yeater, K., Lahner, B., Yakubova, E., et al. (2014). Worldwide genetic diversity for mineral element concentrations in rice grain. Crop Science, 55(1), 1-18.

Reason, D.A.. Watts, M.J., Devez, A., Broadley, M.R. (2015). Quantification of phytic acid in grains, British Geological Survey Open Report, OR/15/070, 18pp.

Rothenberg, S.E., Mgutshini, N.L., Bizimis, M., Johnson-Beebout, S.E., \& Ramanantsoanirina, A. (2015). Retrospective study of methylmercury and other metal(loid)s in Madagascar unpolished rice (Oryza sativa L.). Environmental Pollution, 196, 125-133.

Siyame, E.W.P., Hurst, R., Wawer, A.A., Young, S.D., Broadley, M.R., Chilimba, A.D.C., et al. (2013). A high prevalence of zinc- but not iron-deficiency among women in rural Malawi: a crosssectional study. International Journal for Vitamin and Nutrition Research, 83(3), 176-187.

Smith, E., Naidu, R., \& Alston, A.M. (1998). Arsenic in the soil environment: A review. Advances in Agronomy; 64, 149-195. 
Stein, A.J. (2010). Global impacts of human mineral malnutrition. Plant and Soil, 335(1), 133-154.

Stein, A.J., Nestel, P., Meenakshia, J.V., Qaim, M., Sachdev, H.P.S., \& Bhutta, Z.A. (2007). Plant breeding to control zinc deficiency in India: how cost-effective is biofortification? Public Health Nutrition, 10(5), 492-501.

Stroud, J.L., Khan, M.A., Norton, G.J., Islam, M.R., Dasgupta, T., Zhu, Y.-G., et al. (2011). Assessing the labile arsenic pool in contaminated paddy soils by isotopic dilution techniques and simple extractions. Environmental Science Technology, 45, 4262-4269.

United States Department of Agriculture, Agricultural Research Service, USDA-ARS. (2013). USDA National Nutrient Database for Standard Reference, Release 26. http://www.ars.usda.gov/nutrientdata. Accessed September 2014.

United States Environmental Protection Agency, US EPA (1994). Integrated risk information system (IRIS): Cadmium. http://www.epa.gov/iris/subst/0141.htm. Accessed September 2015.

United States Environmental Protection Agency, US EPA (1998). Integrated risk information system (IRIS): Inorganic arsenic. http://www.epa.gov/iris/subst/0278.htm. Accessed September 2015.

United States Food and Drug Administration, US FDA (2013). Analytical results from inorganic arsenic in rice and rice products sampling. http://www.fda.gov/Food/FoodborneIllnessContaminants/Metals/ucm319870.htm. Accessed March 2014.

Verduzco-Gallo, I., Ecker, O., \& Pauw, K. (2014). Changes in food and nutrition security in Malawi: Analysis of recent survey evidence. Working Paper 06. International Food Policy Research Institute, Washington DC, USA. 
Watts, M.J., Button, M., Brewer, T.S., Jenkin, G.R., \& Harrington, C.F. (2008). Quantitative arsenic speciation in two species of earthworms from a former mine site. Journal of Environmental Monitoring, 10(6), 753-759.

Watts, M.J., Joy, E.J.M., Young, S.D., Broadley, M.R., Chilimba, A.D.C., Gibson, R.S., et al. (2015). Iodine source apportionment in the Malawian diet. Scientific Reports, 5(15251). doi:10.1038/srep 15251 .

Wessells, K.P., \& Brown, K.H. (2012). Estimating global prevalence of zinc deficiency: results based on zinc availability in national food supplies and the prevalence of stunting. PLoS ONE, 7(11), e50568. doi:10.1371/journal.pone.0050568.

White, P.J., \& Broadley, M.R. (2009). Biofortification of crops with seven mineral elements often lacking in human diets - iron, zinc, copper, calcium, magnesium, selenium and iodine. New Phytologist, 182(1), 49-84.

Williams, P.N., Lombi, E., Sun, G.-X., Scheckel, K., Zhu, Y.-G., Feng, X., et al. (2009). Selenium characterization in the global rice supply chain. Environmental Science \& Technology, 43(15), 60246030.

Williams, P.N., Price, A.H., Raab, A., Hossain, S.A., Feldmann, J., \& Meharg, A.A. (2005). Variation in arsenic speciation and concentration in paddy rice related to dietary exposure. Environmental Science \& Technology, 39(15), 5531-5540.

World Health Organization, WHO (2008). Worldwide prevalence of anaemia 1993-2005: WHO global database on anaemia. B. de Benoist, E. McLean, I. Egli, M. Cogswell (Eds.). WHO, Geneva. 
World Health Organization, WHO (2001). Arsenic and arsenic compounds. Environmental Health Criteria 224, $2^{\text {nd }}$ ed. WHO, Geneva.

World Health Organization and Food and Agriculture Organization of the United Nations, WHO \& FAO. (2004). Vitamin and mineral requirements in human nutrition. WHO, Geneva.

Yang, Q.W., Lan, C.Y., Wang, H.B., Zhuang, P., \& Shu, W.S. (2006). Cadmium in soil-rice system and health risk associated with the use of untreated mining wastewater for irrigation in Lechang, China. Agricultural Water Management, 84(1-2), 147-152.

Yang, Q.W., Shu, W.S., Qiu, J.W., Wang, H.B., \& Lan, C.Y. (2004). Lead in paddy soils and rice plants and its potential health risk around Lechang lead/zinc mine, Guangdong, China. Environment International, 30, 883-889.

Zia, M.H., Watts, M.J., Gardner, A., \& Chenery, S.R. (2015). Iodine status of soils, grain, crops, and irrigation waters in Pakistan. Environmental Earth Sciences, 73(12), 7995-8008. 
Table 1. Total concentrations of calcium, copper, iron, iodine, magnesium, manganese, selenium, zinc, arsenic, cadmium and lead (Ca, $\mathrm{Cu}, \mathrm{Fe}, \mathrm{I}, \mathrm{Mg}, \mathrm{Mn}, \mathrm{Se}$, $\mathrm{Zn}, \mathrm{As}, \mathrm{Cd}, \mathrm{Pb}$ ), inorganic arsenic (i-As) and phytic acid (PA) in rice grain grown in Malawi. Q1 and Q3 are first and third quartiles, respectively. Mean and maximum dietary element supplies from white rice among households consuming rice are reported (see methods). Arsenic speciation was conducted for samples with $>0.02 \mathrm{mg} \mathrm{kg}^{-1}$ total As $(\mathrm{n}=17)$.

\begin{tabular}{|c|c|c|c|c|c|c|c|c|c|}
\hline Element & Mean & StDev & Min & Q1 & Median & Q3 & Max & \multicolumn{2}{|c|}{ Consumption } \\
\hline & \multicolumn{7}{|c|}{$\mathrm{mg} \mathrm{kg}^{-1} \mathrm{DW}$} & \multicolumn{2}{|c|}{ mg capita $^{-1} \mathrm{~d}^{-1}$} \\
\hline \multicolumn{8}{|c|}{ Brown rice $(\mathrm{n}=33)$} & mean & maximum \\
\hline $\mathrm{Ca}$ & 72.6 & 32.6 & 35.6 & 55.4 & 66.5 & 74.5 & 211.5 & 4.46 & 42.3 \\
\hline $\mathrm{Cu}$ & 5.52 & 5.42 & 2.19 & 2.73 & 3.65 & 5.83 & 29.14 & 0.24 & 5.83 \\
\hline $\mathrm{Fe}$ & 32.0 & 26.1 & 12.1 & 17.2 & 22.1 & 35.4 & 119.9 & 1.5 & 24.0 \\
\hline I & 0.007 & 0.018 & $<0.005$ & $<0.005$ & 0.006 & 0.011 & 0.071 & 0.0004 & 0.014 \\
\hline $\mathrm{Mg}$ & 1140 & 214 & 761 & 1010 & 1130 & 1280 & 1550 & 75.7 & 310 \\
\hline $\mathrm{Mn}$ & 20.1 & 10.5 & 12.3 & 15.0 & 18.2 & 21.1 & 74.4 & 1.22 & 14.9 \\
\hline $\mathrm{Se}$ & 0.041 & 0.057 & $<0.005$ & 0.010 & 0.025 & 0.043 & 0.300 & 0.0017 & 0.060 \\
\hline $\mathrm{Zn}$ & 18.8 & 4.3 & 13.9 & 15.8 & 17.0 & 20.4 & 34.0 & 1.14 & 6.8 \\
\hline PA & 5580 & 1290 & 3600 & 4680 & 5440 & 6500 & 9600 & 364 & 1920 \\
\hline As & 0.040 & 0.034 & $<0.003$ & 0.007 & 0.030 & 0.075 & 0.100 & 0.002 & 0.020 \\
\hline
\end{tabular}




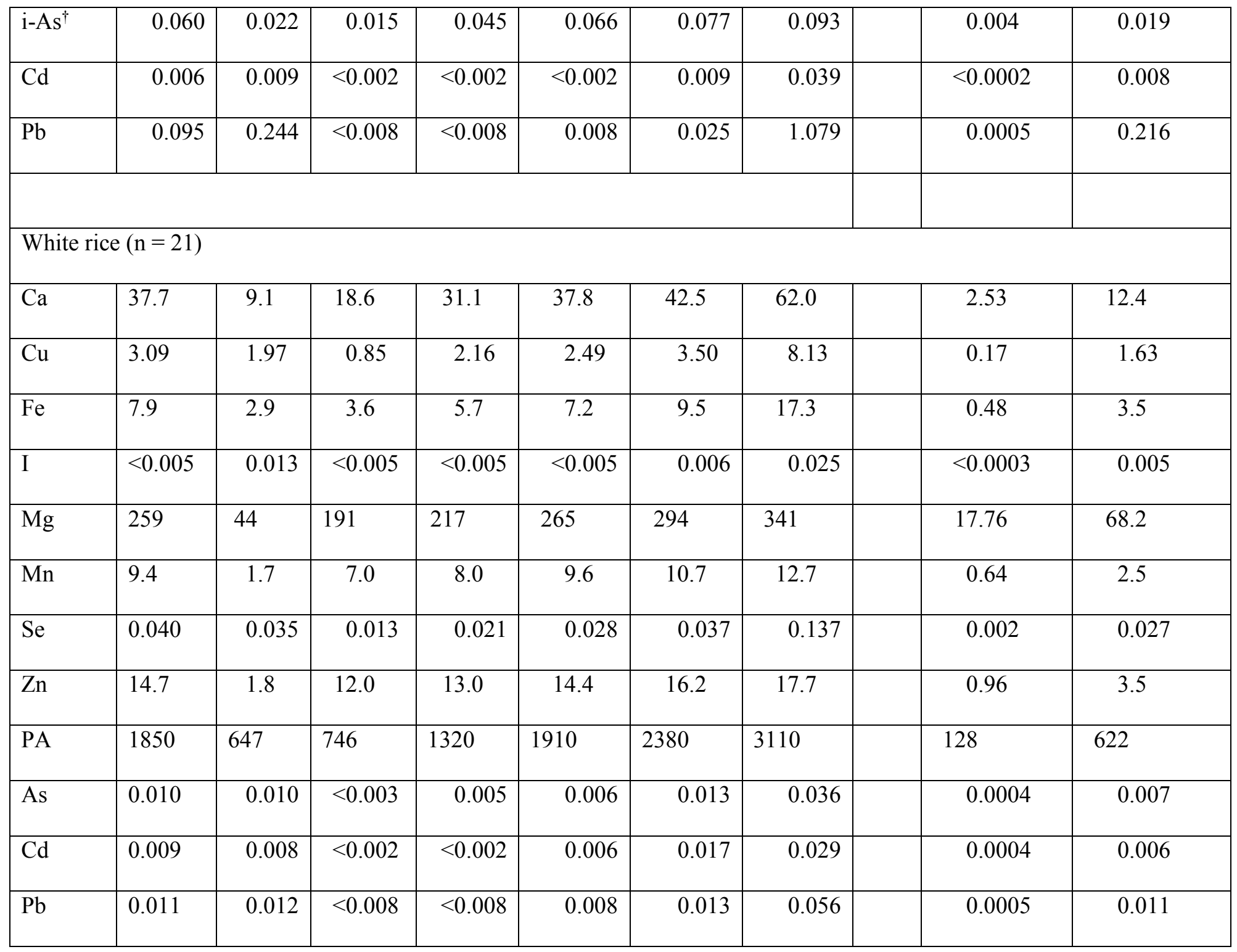


${ }^{\dagger}$ Arsenic speciation was conducted for samples with $>0.02 \mathrm{mg} \mathrm{kg}^{-1}$ total As $(\mathrm{n}=17)$. 


\section{Figures}

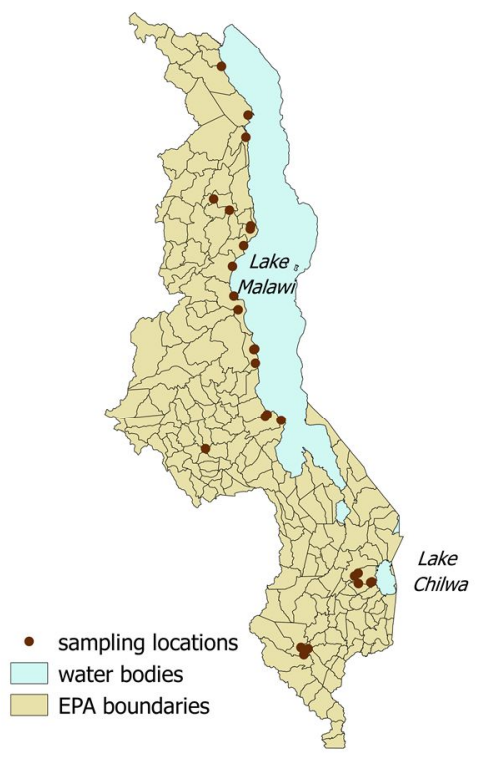

Fig. 1 Rice sampling locations in Malawi. Mapping software: QGIS Geographic Information System v.2.10.1. Open Source Geospatial Foundation. http://qgis.osgeo.org 

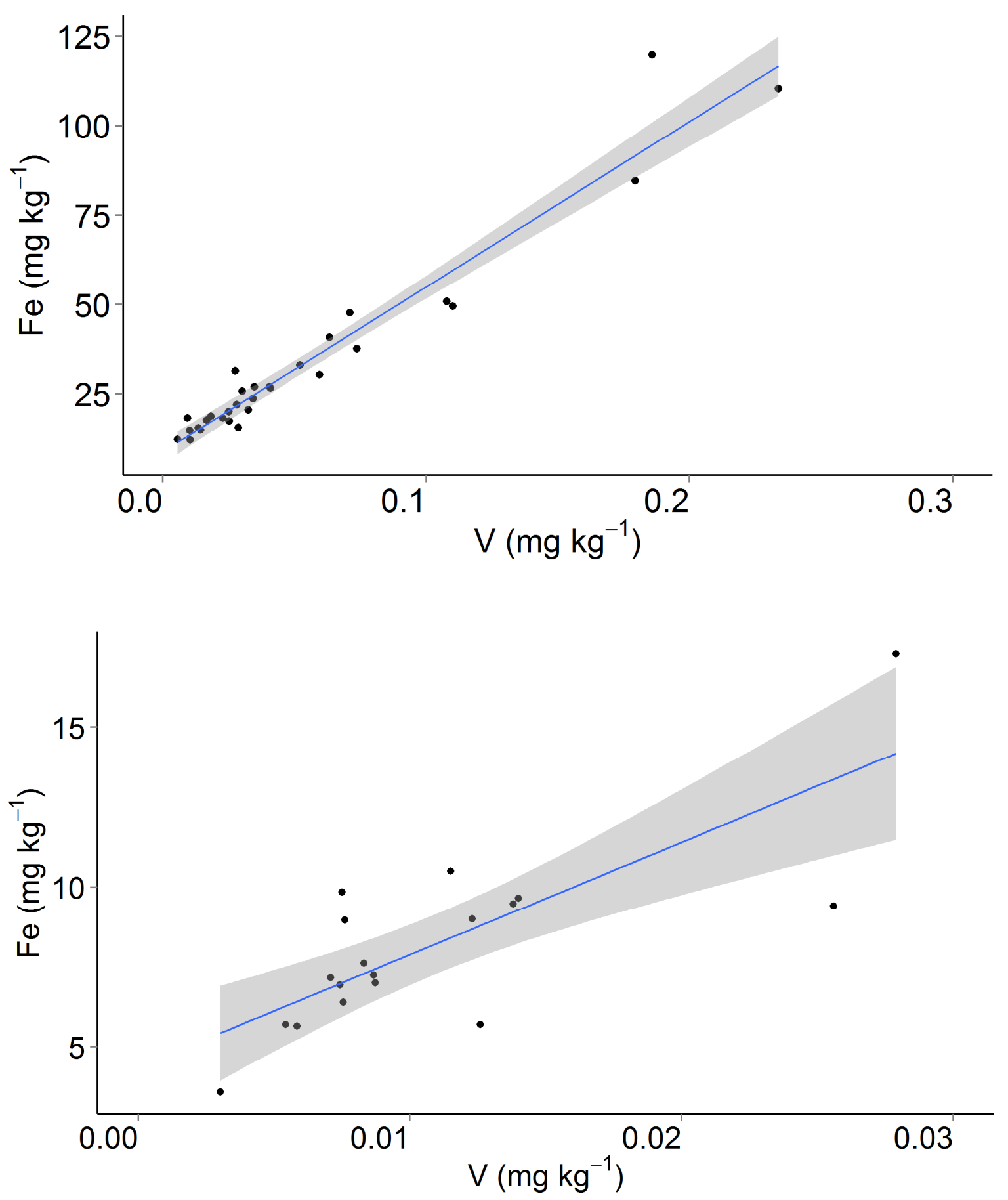

Fig. 2 Concentration of iron (Fe) as a function of vanadium (V) concentration in the grain of (a) brown rice and (b) white rice samples from Malawi. The grey envelope represents $97.5 \%$ confidence interval of the best-fit line. The strong correlation indicates that the majority of Fe is likely to be in soil dust deposits on the surface of the grains. Graphing software: R (v.3.2.2; R Foundation for Statistical Computing, Vienna, Austria) 


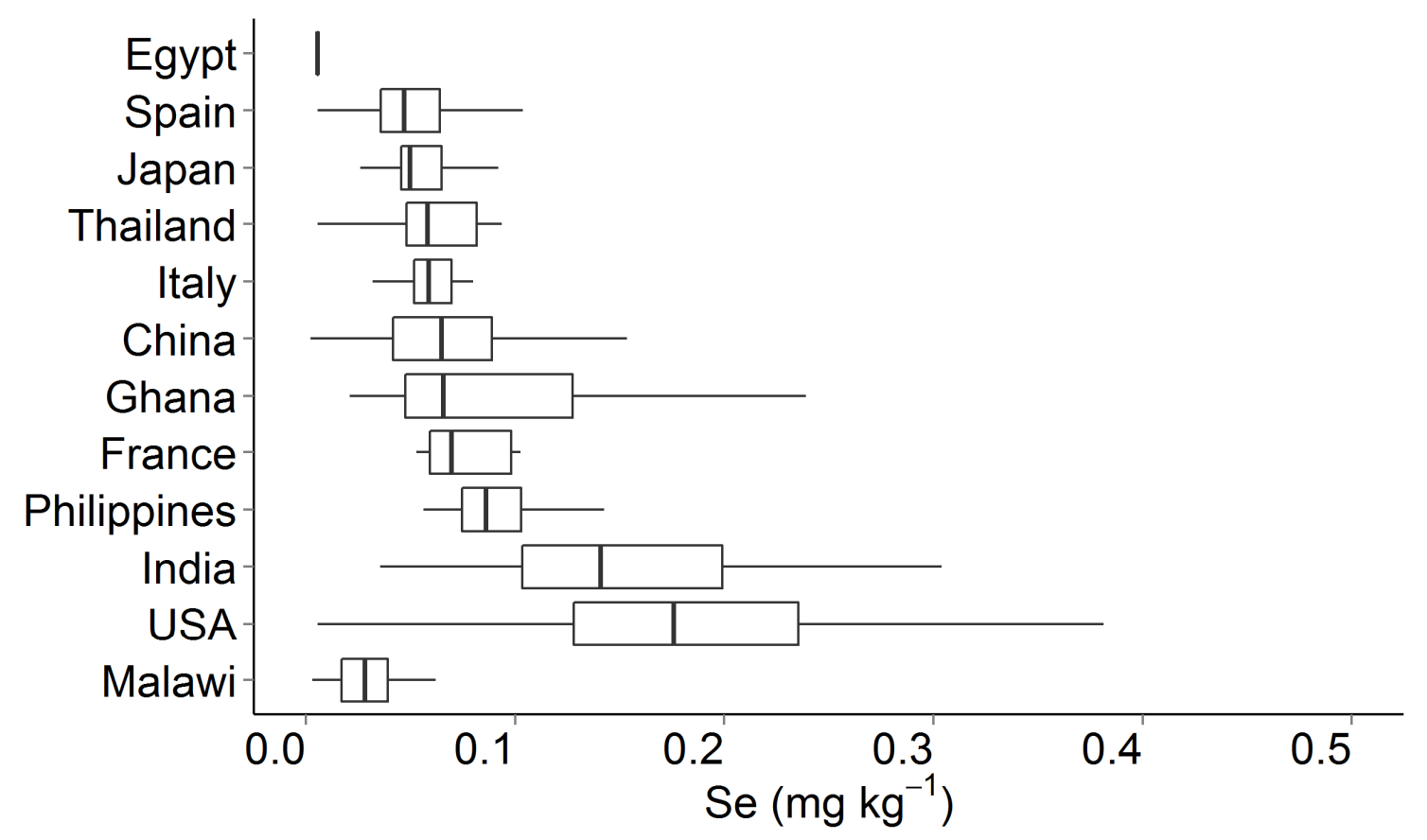

Fig. 3 Concentrations of selenium (Se) in brown and white rice grain. Data for countries other than Malawi are from market-based surveys (Williams et al. 2009; Adomako et al. 2011) with raw data kindly provided on request. Boxes represent the inter-quartile range (IQR) and the mid-line represents the median. Whiskers represent highest and lowest concentrations within $1.5^{*} \mathrm{IQR}$ of the box ends. Graphing software: R (v.3.2.2; R Foundation for Statistical Computing, Vienna, Austria) 

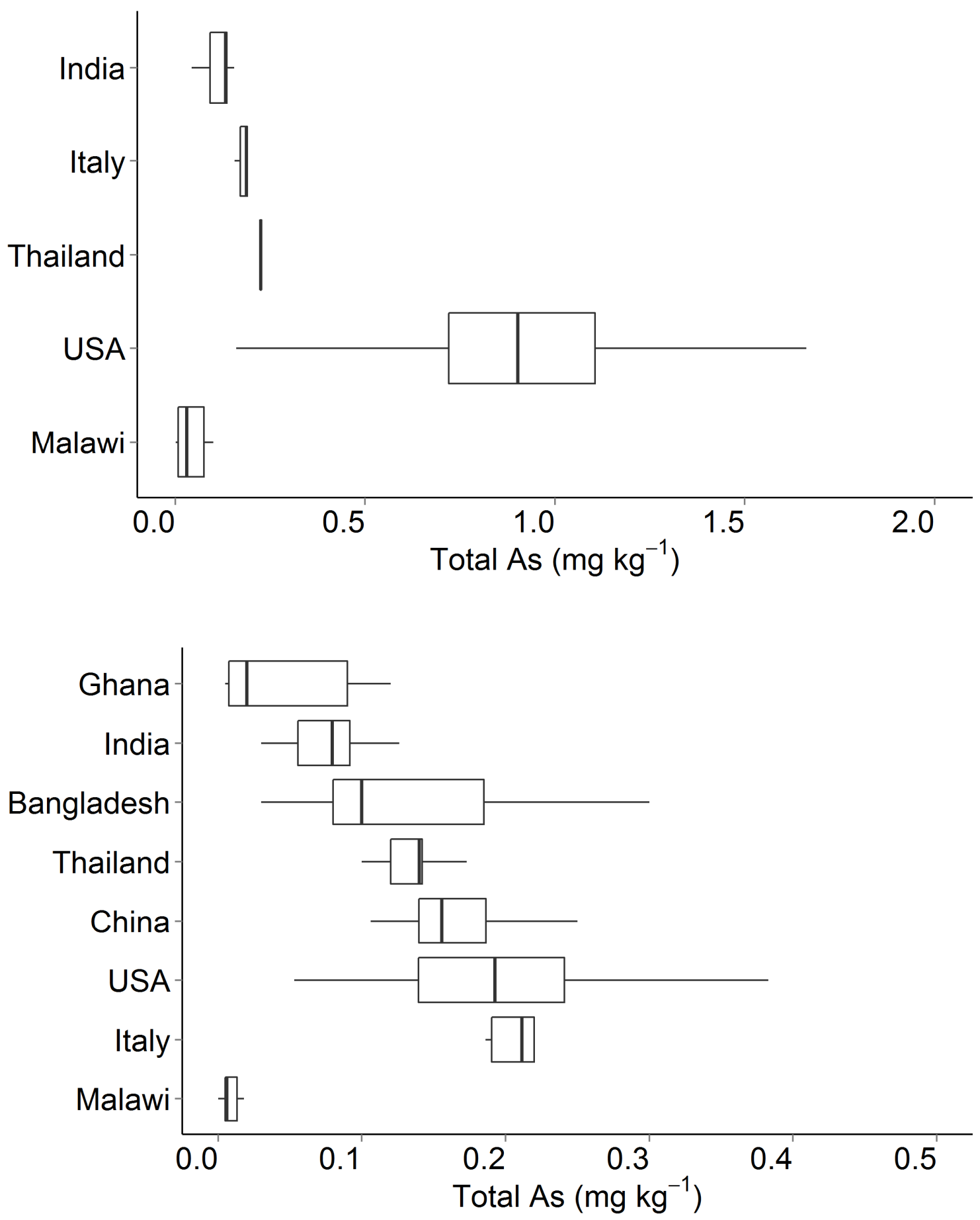


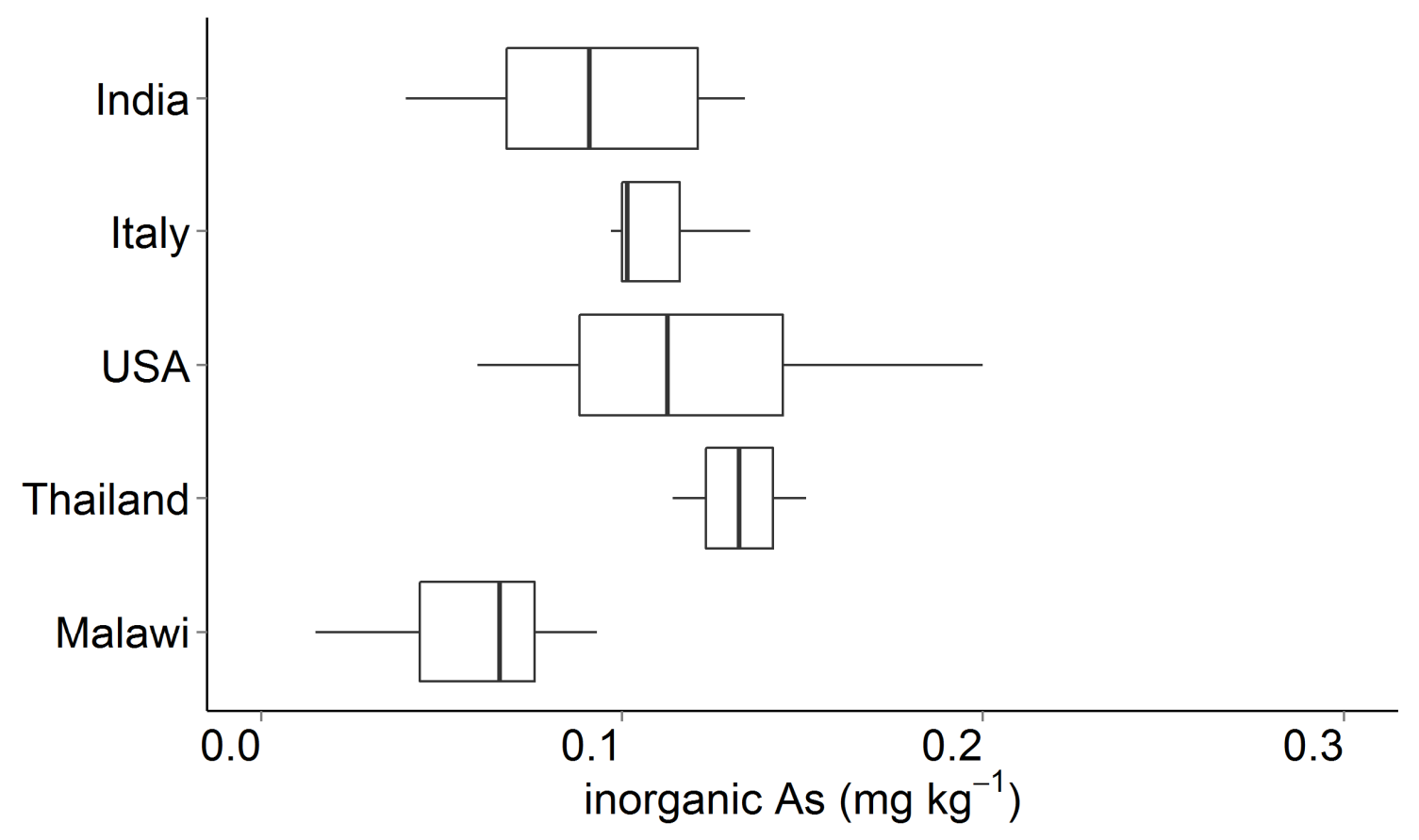

Fig. 4 Concentrations of arsenic (As) in rice grain. Panels (a) and (b) are total As in brown and white rice, respectively; (c) is inorganic As in brown rice. All concentrations are on a dry weight basis. Data for Bangladesh, China, Ghana, India, Italy and Thailand are from a market-based survey (Meharg et al. 2009) with raw data kindly provided on request. Data for the USA are from market surveys and field studies (US FDA 2013; Pinson et al. 2014). Boxes represent the inter-quartile range (IQR) and the midline represents the median. Whiskers represent highest and lowest concentrations within $1.5^{*} \mathrm{IQR}$ of the box ends. Graphing software: R (v.3.2.2; R Foundation for Statistical Computing, Vienna, Austria)

\section{Additional files}

Online Resource 1. Recovery of elements and phytic acid (PA) from certified reference materials (CRMs).

Online Resource 2. Arsenic (As) speciation in rice samples with total As $>0.02 \mathrm{mg} \mathrm{kg}^{-1}$.

Online Resource 3. Elemental concentrations in 54 rice samples from Malawi.

Online Resource 4. Phytic acid (PA) concentrations and PA:metal ion molar ratios in brown and white rice samples from Malawi.

Online Resource 5. Risk of cancer due to exposures to arsenic or cadmium in Malawian rice. 